Counsellia: Jurnal Bimbingan dan Konseling

Volume 11 (1) 1 - 16 Mei 2021

ISSN: 2088-3072 (Print) / 2477-5886 (Online)

DOI: $10.25273 /$ counsellia.v11i1 xxxx

Available online at: http://e-journal.unipma.ac.id/index.php/JBK

\title{
Mengembangkan Potensi Intelektual dan Emosional Mahasiswa yang Kurang Mampu
}

\author{
Muhammad Adnan Alkatiri ${ }^{1}$, Casmini Casmini ${ }^{2}$ \\ ${ }^{1}$ Program Studi Pascasarjana UIN Sunan Kalijaga Yogyakarta \\ Adnanalkatiri96@gmail.com \\ ${ }^{2}$ Fakultas Dakwah dan Komunikasi UIN Sunan Kalijaga Yogyakarta \\ casmini@uin-suka.ac.id
}

\begin{abstract}
Abstrak
Penelitian ini bertujuan untuk mendeskripsikan upaya mahasiswa kurang mampu dalam mengembangkan potensi intelektual dan emosional yang secara bertahap dapat mencapai prestasi akademik dan sekaligus kecerdasan emosional yang memuaskan. Penelitian ini bersifat kualitatif deskriptif dengan metode penggalian data melalui observasi wawancara mendalam pada subjek tunggal pada fokus upaya mahasiswa kurang mampu dalam mengembangkan potensi intelektual dan emosional. Hasil penelitian menunjukkan bahwa cara yang ditempuh untuk mencapai puncak kecardasan intelektual adalah dengan melatih kecerdasan emosional seperti pembiasaan diri, menstimulus diri, mengenali potensi diri dan memotivasi diri sehingga dapat menghasilkan beasiswa sebagai wujud dari prestasi yang gemilang dan cita-cita yang diharapkan meskipun dengan kondisi ekonomi yang terbatas.
\end{abstract}

Abstract

This study aim to describe the efforts of underprivileged student in developing intellectual and emotional potential which can gradually achieve satisfactory academic achievement and emotional intelligence. This researeh is qualitative descriptive with data mining method through in depth interview observation on a single subject which focuses on the efforts of underprivileged student in developing intellectual and emotional potential. The result showed that the way to reach the peak of intellectual acumen is to train emotional intelligence such as self habituation, self stimulation, self recognition and self motivation so as to produce scholarsip as a manifestation of glorious achievements and aspiration expected even and economic conditions limited.

Keywords: Mengembangkan Potensi, Kecerdasan Intelektual, Kecerdasan Emosional.

\section{Received ; Accepted ; Published}

Citation: Alkhatiri, Casmini. (2021). Mengembangkan Potensi Intelektual Dan Emosional Mahasiswa Yang Kurang Mampu. Counsellia: Jurnal Bimbingan dan Konseling, 11(1), 1 - 16. Doi.org/10.25273/counsellia.v11i16603

\section{(c) $)$ EY-NC-SA}

Copyright (C2021 Counsellia: Bimbingan dan Konseling Published by Universitas PGRI Madiun. This work is licensed under the Creative Commons Attribution-NonCommercialShareAlike 4.0 International License 


\section{PENDAHULUAN}

Potensi diri merupakan kemampuan dan kekuatan yang dimiliki individu namun masih terpendam yang perlu diwujudkan dalam kemanfaatan dalam kehidupan bagi dirinya (Habsari, 2005). Potensi diri sebagai sifat dasar/fitrah seseorang memiliki peluang besar untuk dikembangkan (Majdi, 2007), yang diharapkan berbuah prestasi (Ahmadi \& Supriyono, 2007). Jika hal ini diupayakan, maka cita-cita masa depan akan mudah diraihnya. Kesadaran serta pemahaman akan potensi yang dimiliki oleh pemiliknya sangatlah penting untuk disesuaikan dengan tujuan atau pekerjaan yang merupakan citacitanya (Werther Jr \& Davis, 1985). Hal itu agar antara potensi diri dengan cita-cita, seperti jenis pekerjaan yang dipilihnya tersebut berjalan selaras dan sebanding (Havighurst, 1948). Latihan dan belajar dimaksudkan agar seseorang memperoleh pemahaman kuat mengenai potensi tersebut dan memberi pengaruh baik yang dapat menunjang karir dalam dunia pekerjaan (Sari, 2017). Inilah cara yang harus dilakukan oleh seseorang untuk menumbuh kembangkan potensi dirinya secara esensial.

Pengembangan potensi diri identik dengan perubahan sebagai hasil dari latihan dan belajar demi meningkatkan serta menciptakan kreasi dan prestasi yang baru (Prawira \& Atmaja, 2012). Belajar merupakan proses pengembangan dan perubahan diri yang diungkapkan dalam bentuk tingkah laku berdasarkan latihan serta pengalaman (Abdurrahman, 2003). Belajar yang baik akan menghasilkan prestasi sebagai sebuah tingkat atau taraf keberhasilan dari proses pembelajaran dan pengasahan potensi diri sehingga melahirkan kecerdasan yang khusus (Syah, 2009), sebagai hasil dari prestasi dan kreasi yang dibentuk dan diraih dengan cara belajar serta berlatih. Kecerdasan selalu menunjukkan perubahan yang berkembang secara terus menerus dan dinamis, yang tidak terfokus pada bentuk pencapaian seseorang secara statis, namun inti dari kecerdasan pun dilihat dari kreatifitas seseorang yang selalu menciptakan sesuatu yang baru (Gardner, 2003). Pada tahun 1999 Gardner telah menambah sembilan kecerdasan yang memiliki potensi untuk dikembangkan dalam diri manusia yaitu, logical-mathematical, linguistic, intrapersonal, interpersonal, musical, existentialist, bodily-kinesthetic dan visual-spatial dan naturalits (Bowles, 2008). Kesembilan kecerdasan tersebut kebanyakan digolongkan ke dalam bentuk kecerdasan intelektual dan emosional.

Berdasarkan Kamus Besar Bahasa Indonesia, intelektual adalah pintar, cerdas menalar, menganalogikan, menganalisa dan memecahkan sesuatu dengan ilmu pengetahuan (Kamus Besar Indonesia, 2000), setiap orang berpikir menggunakan akal pikiran yaitu intelektual, tercapai dan terpecahnya suatu tujuan atau masalah intinya ditentukan oleh kecerdasan intelektualnya. Orang cerdas dari segi intelektual pada intinya adalah orang yang mempunyai pemahaman serta pemikiran yang mendalam akan hal-hal abstrak dan konkret, cerdas dalam memberikan ide cemerlang yang tepat dan sesuai dengan ilmu pengetahuan (Yani, 2011). Kecerdasan intelektual adalah cara yang digunakan untuk menghadapi sesuatu hal yang baru dengan cara berpikir dan memahami hal baru tersebut untuk menyesuaikan diri (Purwanto, 2003). Sedangkan berpikir menggunakan cara kerja otak dalam aspek intelektual diiringi dengan semangat yang sabar dan ketekunan dalam mengelolah emosi diri sendiri merupakan bagian dari kecerdasan emosional (Melandy \& Nurma, 2006).

Kecerdasan emosional adalah kecakapan atau kemampuan untuk mengenali dan mengelola emosi dalam diri, memotivasi diri dan orang lain serta memahami emosi orang 
lain untuk menjalin hubungan yang baik dengan orang di luar diri sendiri (Daniel, 2003). Bentuk dari kecerdasan emosional pada intinya adalah mengatur, mengolala dan menyeimbangkan emosi dalam diri serta memotivasi diri dan memahami emosi orang lain agar dapat menjalin hubungan baik dengan orang lain tersebut. Selain itu kecerdasan emosional adalah sebagai sumber kepekaan dalam memahami dan merasakan informasi serta koneksi akan hal-hal yang berhubungan dengan perasaan manusia (Rachmi, 2011). Pintar dalam memahami kepekaan yang datang dari dalam dan luar diri, seperti situasi, termasuk orang lain merupakan ciri-ciri orang yang memiliki kecerdasan emosional yang tinggi.

Seseorang dapat dikatakan cerdas secara intelektual dan emosional ketika seseorang mampu menggunakan kemampuan berpikirnya untuk mengatasi kebutuhan diri serta mampu mengatasi problem rohani sesuai dengan konteks real dalam kehidupan nyata (Crow and Crow, 1984). Proses berpikir tersebut juga ditunjang dengan kesabaran dan pengendalian emosi diri agar tetap semangat belajar untuk memecahkan masalah dengan perasaan damai hingga mendapat hasil yang terbaik (Mangal, 2002). Kemudian, seorang mahasiswa dapat dikategorikan dalam kriteria ini ketika ia cerdas pada aspek intelektual, atau dengan kata lain cerdas secara kognitif pada proses perkuliahan hingga memperoleh hasil yang sangat baik dan memuaskan, kemudian juga diikuti dengan semangat dan kekuatan positif dari dalam diri sebagai kecerdasan emosionalnya.

Penelitian ini berfokus pada proses pengembangan potensi intelektual dan emosional dengan subjek seorang mahasiswa yang berasal dari keluarga kurang mampu kemudian ditunjuk menjadi dosen pada Stikes Halmahera, Maluku Utara dengan menggunakan ijazah Strata Satu asal Universitas Negeri Samratulangi, Manado. Subyek mempunyai pengetahuan yang tinggi dan kuat pada bidang Ilmu Pengetahuan Alam meliputi Biologi, Kimia dan Fisika. Kemampuan dan pengetahuannya tersebut membuatnya menjadi lulusan terbaik pada jenjang strata satu pada Jurusan Farmasi dengan predikat Cumlaude. Stikes memberikan dana pendidikan sebesar 12 Juta Rupiah setiap semester kepada subjek untuk melanjutkan pendidikan di Universitas Ahmad Dahlan, Yogyakarta, dengan jurusan yang sama, yaitu Farmasi. Pentingnya penelitian ini diangkat dan berbeda dari penelitian yang lain, sebab subjek menyadari bahwa dengan keadaannya yang kurang mampu ia harus belajar ekstra giat berdasarkan kekuatan emosional yang ia kembangkan di dalam diri subjek yang dapat membuatnya konsisten dalam belajar dan memperoleh beasiswa sebagai jalan untuk meraih kesusksesan karena kondisi ekonomi yang tidak memungkinkan.

Penelitian ini bertujuan untuk mendeskripsikan proses yang ditempuh oleh mahasiswa kurang mampu dalam upayanya mengembangkan potensi intelektual dan emosional yang secara bertahap dapat mencapai prestasi akademik dan sekaligus kecerdasan emosional yang memuaskan. Penelitian ini juga melihat bentuk kecerdasan emosional yang menjadi kekuatan pada diri subjek penelitian dalam proses belajar hingga mendapat hasil kecerdasan intelektual yang maksimal. Berawal dari mengembangkan kecerdasan emosional hingga mengembangkan kecerdasan intelektual dan meraih citacita meski dengan keadaan finansial yang tidak menunjang, maka semuanya itu merupakan bentuk kerja keras subjek yang menjadi keunggulan yang perlu digali dalam penelitian ini. 


\section{METODE PENELITIAN}

\section{Rancang Penelitian}

Penelitian ini menggunakan jenis metode penelitian kualitatif deskriptif yakni menganalisis penjelasan yang diberikan subjek berupa peristiwa real berpatokan kepada pertanyaan yang diberikan peneliti dalam wawancara mengenai proses pengembangan potensi diri mahasiswa dan hasil yang timbul dari aspek kecerdasan intelektual dan emosional (Semiawan, 2010).

\section{Sumber Data}

Sumber data yang dilakuakan peneliti yakni menggali informasi dari subjek sebagai sumber data yang diteliti dengan melakukan tanya jawab berdasarkan situasi dan kondisi yang nyaman dan strategis. Penjelasan yang diberikan oleh subjek secara substantif yakni tentang bagaimana upaya yang dilakukan mahasiswa dalam proses menyelesaikan studi dan apa hasil yang dapat dirasakan hingga menjadi kontribusi bagi dunia akademi khusunya bidang farmasi sebagai jurusan yang diambil di bangku perkuliahan strata dua. Peneliti mencatat semua uraian yang dijelaskan oleh subjek penelitian terkait penjelasan yang diberikannya kemudian data dikumpulkan dan diambil data yang sesuai dengan pembahasan yang dimaksud.

\section{Teknik Pengumpulan Data}

Metode pengumpulan data yang digunakan pada penelitian ini adalah metode observasi dan wawancara. Pengumpulan data dilakukan terlebih dahulu melalui observasi, yaitu peneliti mengamati usaha pengembangan potensi para mahasiswa serta melihat hasil pencapaian khusus di bidang intelektual dan emosional (Setiawan, 2018). Peneliti melakukan pendekatan secara personal yang membutuhkan waktu yang cukup lama. Waktu yang digunakan dalam teknik obeservasi kurang lebih dua bulan terkait upaya belajar yang dilakukan dalam menyelesaikan masa perkuliahan dengan mengembangkan semua kemampuan sebagai proses dan cara sehingga muncul prestasi baru yang bermanfaat sebagai indikator dari hasil pencapaian yang diraih. Peneliti melakukan wawancara setelah selesai observasi, jenis wawancara yang dipilih adalah wawancara tidak terstruktur, yaitu peneliti melakukan pertanyaan informal dengan tidak menggunakan daftar pertanyaan kepada subjek penelitian akan tetapi pertanyaan bebas namun tidak keluar dari topik penelitian dan tetap masih berhubungan dengan topik tersebut, yakni pengembangan potensi diri mahasiswa dari aspek intelektual dan emosional (Holloway, 2007).

\section{Teknik Analisis Data}

Di sini peneliti menganalisa dan mendeskripsikan proses subjek dalam mengembangkan potensi dari kecerdasan intelektual dan emosional selama kuliah melalui proses yang di tempuh. Subjek yang diteliti berjumlah satu orang dari pendidikan konsentrasi farmasi

\section{HASIL DAN PEMBAHASAN}

\section{Hasil}

Data didapatkan dari proses wawancara yang dilakukan di tempat tinggal (kos) peneliti. Peneliti mengundang subjek untuk bertemu dan bersilaturahmi dengan peneliti karena masih merupakan kerabat dekat waktu di Manado. Hasil yang diperoleh dengan menggunakan teknik observasi dan wawacara pada subjek penelitian tersebut 
menyangkut pengembangan potensi diri dari aspek kecerdasan intelektual dan emosional berikut hasil penelitian yang dijelaskan oleh subjek penelitian tersebut.

\section{Profil Subjek}

Subjek dalam penelitian ini adalah seorang mahasiswa jurusan farmasi Universitas Ahmad Dahlan Yogyakarta jenjang Strata Dua yang berinisial RM. Subjek berasal dari Manado dengan latar belakang keluarga menengah ke bawah. Semua riwayat pendidikan subjek ditempuh di Manado sejak Sekolah Dasar hingga masuk jenjang pendidikan Strata Satu. Sejak duduk di bangku Sekolah Menengah Atas, subjek menggeluti Jurusan Ilmu Pengetahuan Alam seperti, fisika, kimia, matematika dan biologi. Jurusan tersebut ditekuninya dengan belajar hingga menjadi kebiasaan rutin yang selalu dilakukannya di rumah secara berulang-ulang setiap hari. Kebiasaan tersebut berhasil mengantarkannya ke puncak prestasi, salah satunya beasiswa yang dia dapatkan dalam melanjutkan studi strata duanya.

\section{Pembiasaan Diri}

Proses dan tahapan mengembangan potensi diri juga dilihat dari proses atau tahapan kebiasaan diri RM, selaku subyek penelitian. Hal ini dikarenakan dengan menumbuhkembangkan kebiasaan diri tersebut secara bertahap, maka akan terjadi pula proses sekaligus cara mengembangkan potensi diri sebagaimana yang dikemukakan oleh RM, bahwa;

"Kalau menurut saya proses pembiasaan diri itu, tahapan-tahapan yang dilakukan atau dialami sehingga yang darinya tidak terbiasa bisa menjadi bisa menjadi terbiasa. Contoh dari hal tersebut adalah pada awalnya terkadang saya harus memaksakan diri dalam mempelajari dan melakukan hal-hal baru. Untuk memudahkan hal tersebut saya selalu awali dengan durasi yang pendek. Dengan hanya melakukannya beberapa menit setiap harinya. Setelah mulai terbiasa barulah saya mencoba untuk meningkatkan durasi dan kualitasnya secara perlahan-lahan.

Tahapan pembiasaan diri tersebut membutuhkan proses agar mudah untuk ditingkatkan secara maksimal melalui bentuk-bentuk upaya atau cara yang dilakukan oleh RM, selaku subyek penelitian.

"Kalau bentuk-bentuk upaya pembiasaan diri itu usaha yang dilakukan agar bisa terbiasa. Kalau dari aku memulai dari hal-hal kecil seperti secara konsisten bangun pagi. Membuat jadwal pembelajaran pada jam yang sama setiap harinya. Pelajaran tersebut biasa saya ulangi dan evaluasi kembali di rumah jika telah dijelaskan oleh guru atau dosen di sekolah atau di kampus. Cara ini merupakan cara yang dilakukan agar pelajaran yang dijelaskan oleh guru atau dosen materinya dapat dikuasai sepenuhnya dan melekat kuat di ingatanku".

Adapun kegiatan keseharian yang biasa dilakukan oleh RM mulai dari bangun pagi hingga malam menjelang sebagai cara untuk mengembangkan potensi dirinya, dia menjelaskan bahwa;

"Biasanya cara yang sering saya laksanakan sehari-hari adalah pada saat bangun tidur saya sholat subuh, kemudian beberapa saat saya siap-siap untuk berangkat ke sekolah. Pulang sekolah aku makan siang setelah itu, istirahat siang setelah bangun tidur aku membuka pelajaran dan mengulang kembali meteri pelajaran yang baru didapatkan dari guru atau dosen tadi. Rasa penasaran saya dengan meteri tadi yang dijelaskan oleh guru atau dosen di sekolah dan kampus menjadikan saya untuk mempelajarinya lebih dalam. Mengingat saya mengambil jurusan ilmu pengetahuan alam dari sejak SMA maka saya pun sering mengulangi dan mendalami pelajaran yang diberikan guru tersebut, seperti biologi, fisika dan kimia". 
Kebiasaan tersebut dimulai dari SMA sekolah Menengah Atas hingga kuliah dan menjadi seorang mahasiswa strata satu. Hal itu terbukti dengan keseriusannya dalam belajar sebagai usaha dan upayanya dalam mengembangkan potensi diri. Bentuk upaya kebiasaan diri ada hasil yang ditimbulkan dan memberikan manfaat bagi RM, selaku subyek penelitian. Hasil tersebut meliputi bidang kecerdasan intelektual dan kecerdasan emosional. Hal ini sebagaimana yang telah diungkapkan RM, bahwa;

"Hasil yang saya peroleh dari pembiasaan diri adalah menambah dan memperkuat wawasan keilmuan saya di bidang intelektual khususnya bidang Ilmu Pengetahuan Alam. Sementara itu dari segi kecerdasan emosional adalah dapat membiasakan diri belajar dan tidak merasa bosan meskipun lama hingga menjadi sebuah hobi yang sangat bermanfaat".

Hasil dari kebiasaan diri subjek yaitu dapat meningkatkan dan menyesuaikan antara pengetahuan intelektualnya dengan bidang keilmuan atau jurusan yang dipilihnya di setiap jenjang pendidikan. Kebiasaan diri tersebut juga sesuai dengan dengan perasaan nyaman dan emosi diri yang terkendali sebagai bentuk dari kecerdasan emosionalnya. Keterbatasan ekonomi merupakan tantangan bagi RM dalam melanjutkan pendidikan dan perkuliahan untuk meraih cita-cita dan masa depannya.

\section{Stimulasi pengembangan potensi diri}

Adanya hal-hal yang merupakan keterbatasan ekonomi RM, selaku subjek penelitian yang hal tersebut sekaligus merupakan proses dari keterbatasan ekonominya dalam mengembangkan potensi diri berupa kecerdasan intelektual dan emosional. Proses tersebut sebagaimana yang dijelaskan olehnya, yaitu;

"Saya berasal dari keluarga yang pas-pasan maka saya tidak ingin membebani kedua orang tua saya. Selain itu niat kemauan saya untuk memenuhi kebutuhan hidup juga mengharuskan saya untuk bekerja".

Bentuk-bentuk upaya dan cara dalam mengembangkan potensi diri baik dari segi kecerdasan intelektual maupun dari segi kecerdasan emosional, sekaligus upaya untuk membantu keterbatasan ekonomi tersebut. Hal ini sebagaimana yang disampaikan oleh RM, selaku subjek penelitian bahwa;

"Saya mencari beasiswa agar bisa terus melanjutkan pendidikan ke jenjang strata dua yang merupakan kemauan dari dalam diri agar dapat membantu perekonomian saya. Selain itu saya bekerja menjadi dosen agar bisa memenuhi keterbatasan ekonomi sekaligus mengembangkan potensi akademik dengan pengetahuan intelektual yang saya miliki”.

Selain itu menurutnya beasiswa juga dapat membantu kondisi perekonomian untuk tetap dapat melanjutkan pendidikan serta mengembangkan potensi dirinya. Hal ini sebagaimana yang dijelaskanya bahwa;

"Hal yang menjadi keterbatasan saya serta kemungkinan dapat menjadi tantangan dan halangan dalam menempuh perkuliahan adalah keterbatasan dalam hal ekonomi sehingga mendorong saya untuk mencari beasiswa dan mengatur keuangan agar tidak terlalu boros".

Keterbatasan ekonomi tersebut memberikan dampak positif sebagai hasil yang diperoleh dari subjek penelitian. Hasil dari keterbatasan ekonomi tersebut memberikan dampak dari segi kecerdasan intelektual dan kecerdasan emosional, sebagaimana yang dijelaskan oleh RM selaku subyek penelitian, bahwa;

"Hasil yang saya peroleh secara tidak langsung mendapatkan kemampuan untuk mengajar ilmu dari segi kecerdasan intelektual. Kegiatan mengajar tersebut juga sebagai dorongan keadaan emosional untuk mencari pendapatan dalam memenuhi kebutuhan." 


\section{Mengenali diri untuk menemukan potensi diri}

Proses mengenali diri dianggap hal yang dibutuhkan oleh RM selaku subjek penelitian, karena dengan hal tersebut dia dapat mempermudah cara serta proses pengembangan potensi diri dengan melihat kondisi dan situasi belajar yang sesuai dengan kebutuhan dan minat dirinya sendiri. Hal ini sebagaimana yang dikemukakan oleh RM sendiri, bahwa;

"Saya mencoba bermacam-macam metode dan cara-cara belajar, hingga mendapatkan metode dan cara yang menurut saya paling efektif serta nyaman untuk saya. Mengenal diri sendiri adalah cara dan metode untuk belajar yang merupakan bagian dari proses dalam mengembangkan potensi diri".

Mengenali diri sendiri merupakan hal yang sangat perlu untuk dilakukan oleh subjek peneliti. Tapi semua itu membutuhkan cara sebagai bentuk-bentuk upaya untuk mengembangkan potensi diri. Cara dan upaya tersebut sebagaimana yang dijelaskan oleh RM, bahwa;

"Melakukan tes IQ sehingga mengetahui kemampuan dalam hal intelektual, melakukan tes kepribadian, dan mencoba berbagai macam cara belajar".

Adapun cara lain yang lebih spesifik dalam belajar umtuk mengembangkan potensi diri adalah sebagaimana yang disampaikan oleh subjek penelitian adalah sebagai berikut;

"Cara pertama yang saya lakukan untuk mengembangkan potensi diri dalam perkuliahan atau belajar yaitu, mengenali diri sendiri karena setiap orang mempunyai keunikan dan cara belajar yang berbeda-beda. Kemudian yang kedua selalu merasa penasaran dan tidak muda puas dengan ilmu yang telah didapatkan. Selanjutnya ketiga tidak takut mencoba hal-hal baru. Yang keempat selalu terbuka dan menerima kritikan orang lain. Kemudian yang terakhir adalah "Persistence" dengan selalu berjuang dan tidak pernah berputus asa".

Mengenali diri sendiri juga merupakan bagian dari proses dan cara yang dijalaninya dalam belajar untuk mengembangkan potensi diri khusus dalam bidang intelektual dan emosional. Hasilnya pun sebagaimana yang disampaikan oleh RM selaku subjek peneliti, bahwa;

"Hasil yang saya rasakan dari segi kecerdasan intelektual yakni membuat saya lebih mudah paham dan mengerti dengan bidang pengetahuan atau materi yang saya pelajari. Selain itu dalam emosional saya adalah dengan mengenal diri sendiri saya dapat dengan nyaman dalam belajar".

Motivasi diri

Dalam proses mengembangan potensi diri subyek ada motivasi yang selalu dipegang teguh untuk mencapai tujuan dan mewujudkan cita-citanya. Hal ini menjadikannya pantang mundur dan selalau berusaha untuk mengembangkan potensi diri dari kecerdasan intelektual dan emosional. Demikian hal tersebut sebagaimana yang dikemukakan oleh subjek penelitian, bahwa;

"Motivasi saya yaitu dengan menyelesaikan pendidikan/kuliah akan memudahkan saya mencapai cita-cita saya. Cita-cita saya yaitu menjadi seorang guru besar/peneliti bidang farmasi, dan berharap ilmu serta hasil penelitian saya dapat berdampak positif bagi masyarakat."

Cara yang lebih spesifik untuk menjaga motivasi belajar dalam mengembangan potensi diri, antara lain sebagaimana yang dijelaskan oleh RM, bahwa;

"Hal yang saya lakukan untuk menjaga semangat akan proses belajar dan pengembangan potensi diri adalah selalu meminta motivasi dan mencari dukungan dari orang tua. Ketika saya memiliki masalah dalam perkuliahan ataupun ketika semangat 
menurun, saya selalu menceritakan hal tersbut kepada orang tua saya. Sehingga orang tua saya selalu memberikan saran dan motivasi. Motivasi lain adalah bergaul dengan teman-teman yang selalu mengajak kearah yang positif seperti belajar dan berdiskusi bersama membuat saya lebih bersemangat dan tidak merasa berjuang sendiri”.

Motivasi dalam bentuk lain adalah menjaga semangat belajar subjek peneliti untuk mengembangkan potensi diri adalah sebagaimana yang ia jelaskan bahwa;

"Cara lain untuk menjaga semanagat belajar sebagai motivasi antara lain, membaca biografi dan kisah-kisah orang sukses khususnya dalam bidang akademik sehingga selalu terpacu untuk bisa seperti mereka. Semua orang pastinya pernah merasakan masa-masa dimana semangat belajar dan perjuangan mereka menurun. Saat semangat saya menurun, saya merenung dan mengingat-ingat kembali tujuan saya belajar, tujuan saya kuliah serta telah berapa banyak perjuangan yang telah saya lalui hingga bisa sampai di tahap ini”.

Keberhasilan dan pencapaian dari motivasi diri menjaga semangat belajar dalam mengembangkan potensi diri dari aspek kecerdasan intelektual dan emosional. Ini sebagaimana yang dijelaskan oleh RM, selaku subjek penelitian bahwa;

"Selain beasiswa hal yang menjadi indikator dan pencapaian saya dalam perkuliahan adalah menjadi asisten dosen di tempat saya kuliah dan dipercayakan untuk mengerjakan proyek-proyek penelitian dari dosen. Proyek penelitian tersebut memudahkan saya untuk menyusun tesis dan sebuah jurnal sebagai syarat untuk mengikuti ujian akhir strata dua yakni tesis tersebut, karena dosen memberikan sebagian hasil penelitian yang saya kerjakan untuk dikembangkan di dalam tulisan jurnal sebagai syarat kelulusan dan tesis. Selain itu pencapaian yang saya raih yaitu menjadi dosen di salah satu perguruan tinggi swasta".

\section{Pembahasan}

\section{Pembiasaan diri: upaya}

Proses pengembagan diri adalah pembelajaran yang dilakukan secara bertahap untuk kemudian menjadi kebiasaan diri yang sempurna berdasarkan prosedur dan langkah-langkah yang dibuat (Surya, 2013). Tahapan pembelajaran yang dilakukan subjek adalah menggunakan durasi waktu yang berjenjang dalam mempelajari hal-hal baru agar memudahkan proses pembelajaran berdasarkan kemampuan dan kesanggupan diri hingga menjadi kebiasaan diri yang seutuhnya dalam mempelajari hal baru tersebut. Subjek menggunakan durasi waktu yang singkat untuk proses pertama belajarnya, kemudian durasinya semakin diperpanjang pada proses-proses belajar berikutnya. Tujuan dari tahap pembiasaan diri adalah untuk menjadikan sesuatu yang tidak biasa menjadi terbiasa sebagaimana yang dilakukan oleh subjek sebagai langkah awal dalam mengembangkan potensi diri melalui proses pembiasaan diri tersebut (Hendriana \& Jacobus, 2017).

Bentuk upaya pembiasaan diri adalah cara yang dilakukan subyek secara berulang-ulang untuk meningkatkan kegiatan positif yang dapat menunjang potensi diri (Ulwiyah, 2015). Kegiatan bangun pagi yang dilakukan oleh subjek adalah cara yang digunakannya dalam mengembangkan potensi diri dengan melakukannya secara konstisten, karena hal yang sederhana jika dibiasakan melalui usaha maka akan menjadi bentuk upaya dari pembiasaan diri (Ihsani dkk., 2018). Selain itu bentuk upaya dari pembiasaan diri yang dilakukan subjek adalah dengan cara membuat jadwal pelajaran setiap hari secara rutin serta mengevaluasi dan mengulang kembali materi pelajaran yang didapatkan dari sekolah atau kampus, juga merupakan pembiasaan diri untuk menunjang 
pengembangan potensi diri. Hal ini dimaksudkan untuk dapat menunjang potensi diri melalui pembiasaan diri subjek tersebut (Muthoharoh, 2015).

Pembiasaan diri yang dilaksanakan oleh subjek penelitian memberikan hasil yang maksimal dalam kecerdasan intelektual. Hal ini dilihat dari kebiasaan subjek mengulang kembali pelajaran yang didapatkan dari sekolah atau kampus untuk memperkuat pemahaman akan pengetahuan intelektualnya (Rahmawati, 2018). Jadi pemahaman tinggi subjek adalah sebagai hasil kecerdasan intelektual khususnya di bidang ilmu pengetahuan alam, yang diperoleh dengan cara mengulang kembali materi pembelajaran yang dijelaskan oleh guru dan dosen yang ada di sekolah dan kampus. Selain itu hasil yang muncul dari kecerdasan emosional adalah kebiasaan positif bangun pagi dan mengatur jadwal pelajaran dapat diselaraskan dengan kondisi kesiapan emosionalnya karena terbiasa. Aktivitas bangun pagi dan mengatur jadwal mata pelajaran adalah kebiasaan diri yang akan terus menerus terbiasa dan dapat mempengaruhi keadaan emosional (Pranita, 2012).

\section{Mengelola Diri dalam Keterbatasan Ekonomi}

Proses keterbatasan ekonomi merupakan sebuah hal yang sulit yang dialami oleh subjek bahkan menjadi penghalang dan ancaman dalam mengembangkan potensi dirinya (Leinonen dkk., 2002). Namun hal ini tidak menyurutkan niat subjek untuk tetap melanjutkan kuliah dan mengembangkan potensi diri hingga dapat meraih cita-cita dan prestasi. Proses keterbatasan ekonomi lainnya menurut dia adalah kebutuhan hidup yang harus dipenuhi. Menurut subjek keterbatasan ekonomi mengharuskan dia untuk bekerja dalam memenuhi kebutuhan hidup yang dianggapnya kurang dan mempengaruhi semangat belajar dalam mengembangkan potensi diri. Proses keterbatasan ekonomi lainnya dilihat dari tujuan subjek bekerja untuk memenuhi kebutuhan hidup hingga mampu mengembangkan potensi diri, sebab dengan bekerja menurutnya dapat mengurangi keterbatasan ekonomi juga membantu perekonomian orang tua (Nurwati, 2008).

Upaya yang dilakukan oleh subjek dalam mengembangkan potensi diri meskipun dengan kondisi ekonomi yang relatif terbatas adalah dengan cara mencari beasiswa berdasarkan pengetahuan intelektual dan kemampuan akademik. Beasiswa merupakan cara yang ditempuh oleh seseorang yang mengalami keterbatasan ekonomi namun memiliki prestasi yang tinggi dan luar biasa hingga tetap dapat mengembangkan potensi diri khususnya dalam bidang kecerdasan intelektual (Utomo, 2011). Cara lain sebagai bentuk upaya yang dilakukan oleh subjek adalah mengajar dan menjadi dosen agar dapat memenuhi kebutuhan ekonomi. Kemauannya dalam bekerja merupakan kemauan dalam bentuk kecerdasan emosional dari dalam diri agar bisa membantu keterbatasan ekonomi dan kebutuhan dalam perkuliahan hingga dapat meraih cita-cita dan tujuan melalui pengembangan potensi diri. kecerdasan emosional dapat juga dilihat dari bentuk kemauan dan semangat dalam bekerja untuk menunjang kebutuhan diri serta mengembangkan potensi diri (Herawaty, 2016).

Keterbatasan ekonomi memberikan hasil yang bermanfaat dari segi intelektual dan emosional. Mengajar memberikannya dampak baik bagi subjek melalui ilmu pengetahuan yang dimilikinya, karena dengan mengajar dia juga dapat mengembangkan pengetahuan akademis yang dimilikinya. Pengetahuan intelektual akan meningkat jika dikembangkan terus menerus melalui proses pengajaran dari orang yang mempunyai pengetahuan akademik pada masyarakat atau pelajar yang membutuhkan pengetahuan 
tersebut (Saidin, 2004). Subjek yang mengajarkan ilmu pengetahuan akan terus memahami ilmu yang dimilikinya bahkan pengetahuan itu akan meningkat dengan kagiatan mengajar tersebut, karena dengan mengajar secara tidak langsung dia juga telah belajar kembali atas semua pengetahuan yang dimilikinya. Dari segi kecerdasan intelektual pun dapat dilihat bahwa aktifitas mengajar tersebut berdasarkan dorongan dan niat yang kuat dari dalam dirinya untuk memenuhi kebutuhan hidup dalam mengembangkan potensi diri (I. S. Dewi, 2011).

\section{Mengenali diri, Mengembangkan Potensi}

Dalam belajar untuk mengembangkan potensi diri cara yang paling afektif adalah dengan proses mengenali diri sendiri. Tujuan dari proses mengenali diri sendiri adalah untuk meningkatkan kemamapuan diri dalam belajar hingga dapat menemukan cara untuk memecahkan masalah belajar serta dapat mengembangkan potensi diri dari aspek intelektual dan emosional (S. Dewi, 2018). Maka dengan proses mengenali diri sendiri dapat mengetahui kemampuan diri untuk mengembangkan potensi diri. Kemampuan setiap orang memiliki jenis yang berbeda-beda yang merupakan bentuk dari potensi diri yang belum diketahui maka untuk mengetahui kemampuan tersebut perlu adanya proses mengenali diri sendiri dalam belajar (Syaputra et al., n.d. 2018). Jadi proses mengenali diri sendiri merupakan proses untuk mengetahui kemampuan yang dimiliki agar mampu menyesuaikan potensi diri dengan lingkungan.

Upaya yang dilakukan oleh subjek dalam mengenai diri sendiri adalah dengan cara melakukan tes IQ untuk mengetahui kemampuan dan pengetahuan intelektual hingga dapat dikembangkan menjadi potensi (Nyimas Sopiah \& Usman Ependi, 2014). Maka bentuk upaya yang dilakukan oleh subjek dalam mengenali diri untuk mengembangkan potensi diri adalah dengan melakukan tes IQ sekaligus untuk mengetahui kemampuan diri dalam belajar. Selain itu melakukan tes kepribadian merupakan bentuk upaya dari mengenali diri untuk mengetahui kemampuan diri dengan membentuk kepribadian khusus yang dapat disesuaikan dengan cara belajar atau proses memahami sebuah pengetahuan (Periantalo \& Azwar, 2017). Hal ini dapat diartikan bahwa tes kepribadian adalah membentuk kemampuan subjek dengan cara khusus yang ia miliki untuk memahami dan memecahkan masalah dalam belajar sebagai bentuk dari upaya dalam mengembangkan potensi diri. Tes kepribadian juga dapat dikolaborasikan dengan berbagai macam metode dan cara pembelajaran yang dilaksanakan subjek hingga menemukan cara yang mudah serta cocok dengan kenyamana dirinya dalam memahami sesuatu hal dalam proses pembelajaran belajar.

Bentuk upaya yang dilakukan oleh subjek dalam mengembangkan potensi diri dengan mengenali diri sendiri menimbulkan hasil yang maksimal dan bermanfaat dari sisi pengetahuan intelektual dalam memahami sebuah ilmu. Hal ini dapat dilihat dengan kemudahan subjek dalam memahami serta mempelajari pengetahuan sebagai bagian dari kecerdasan intelektual. Selain itu hasil yang dapat dirasakan dan diperoleh oleh subjek dari aspek kecerdasan emosional yakni cara dalam mengatur keadaan diri dan emosi agar muda memecahkan masalah yang menjadi upaya pembelajaran untuk mengembangkan potensi diri. Kecerdasan emosional adalah kecerdasan untuk mengatur keadaan dan emosi dalam diri agar mendapat hasil yang maksimal serta sesuai dengan maksud yang diharapkan, karena kecerdasan emosional merupakan kecerdasan yang menunjang 
perasaan dan situasi mental seseorang dalam belajar hingga mendapat hasil yang baik (Gusniwati, 2015).

\section{Motivasi Diri : mengajarkan Berpikir Kritis dan Mengelola Emosi}

Motivasi subjek dalam belajar yakni dengan menyelesaikan pendidikan dan perkuliahan maka serta mampu dan sanggup untuk mengembangkan potensi diri yang dimilikinya. Motivasi diri adalah semangat dalam diri untuk mencapat tujuan dan cita-cita yang dimaksud melalui segala macam cara dan proses yang menunjang (Hamdu and Agustina, 2011). Cita-cita yang menjadi tujuan utama subjek dalam melaksanakan pendidikan dan perkuliahan adalah menjadi seorang guru besar serta peneliti di bidang farmasi hinggap penelitiannya tersebut dapat bermanfaat bagi masyarakat umum. Citacita ini yang merupakan tahapan motivasi dalam mengembangkan potensi melalui pendidikan dan perkuliahan yang ditempuhnya hingga memperkuat tekatnya untuk tetap berjuang dan semangat dalam belajar. Motivasi merupakan semangat diri yang timbul berdasarkan cita-cita yang menjadi pendorong dan penguat belajar subjek dalam mengembangkan potensi diri hingga dapat mewujudkan cita-cita tersebut (Ulfah dkk., 2016).

Bentuk dan upaya yang subjek lakukan untuk menjaga motivai diri ketika menemukan masalah perkuliahan yakni meminta dukungan dari orang tua dan teman. Hal ini dikarenakan dukungan orang tua, teman serta lingkungan sosial menjadi hal yang sangat berpengaruh terhadap semangat belajar subjek dalam mengembangkan potensi diri (Suciani \& Safitri, 2014). Hal ini membuatnya selalu bersemangat dalam belajar dan meraih tujuan yang diinginkan, karena selalu mendapat dukungan yang membuat subjek merasa tidak berjuang sendirian dalam mengembangkan potensi diri dan meraih cita-cita dengan usaha yang dia lakukan. Belajar dari orang orang yang memiliki inspirasi seperi membaca kisah-kisah biografi tokoh yang sukses di bidang akademik di masa dulu dapat memberikan motivasi serta memacu semangat belajar yang lebih giat untuk memperoleh pengetahuan intelektual maksimal (MZ, 2018). Semua motivasi tersebut juga menimbulkan dampak positif dari dalam diri subjek yakni memacu dan mendorong semangat belajar subjek ke arah yang lebih positif dari segi kecerdasan emosional.

Selain dari pada itu hal yang menjadi motivasi subjek dalam mengembangkan potensi dirinya yaitu adalah mengingat kembali tujuan dia menempuh perkuliahan dan mengeyam pendidikan berdasarkan tahapan dan usaha yang telah dilakukan. Maka semua hal tersebut marupakan bentuk usaha dari motivasi diri dalam mengembangkan potensi diri subjek dalam aspek kecerdasan intelaktual dan emsional. Sebab orang yang memiliki motivasi diri yang besar adalah orang memiliki kecerdasan emosional yang tinggi (Choiriah, 2013).

Berdasarkan pembahasan yang dijelaskan di atas, semua prestasi yang dimiliki subjek penelitian disebabkan kemampuan subjek dalam mengembangkan dan mengelola emosional diri dengan melatih dan membiasakan diri untuk melakukan kegiatan dan aktivitas-aktivitas positif. Latihan tersebut dibiasakan dalam kegiatan pembelajaran dan aktivitas yang bernilai seperti membiasakan diri belajar di rumah dengan durasi yang bertahap, mengatur jadwal aktivitas seperti bangun pagi dan menata kegiatan yang berfaedah mulai pagi hingga malam. Semua itu merupakan kebiasaan yang diolah dengan mengembangkan kecerdasan emosional agar terbiasa dengan aktivitas pembelajaran tersebut hingga memberi hasil yang maksimal khusus dalam kecerdasan intelektual Beberapa hasil dalam bentuk kecerdasan intelektual tersebut diantarnya adalah beasiswa 
yang dimiliki subjek sebagai bentuk indikator pencapaian dari aspek kecerdasan intelektual. Kemudian dipercayakan menjadi asisten dosen untuk mengajar di tempatnya kuliah serta mendapat banyak jenis proyek penelitian di bidang farmasi dan ilmu pengetahuan alam. Proyek penelitian tersebut selain dibuat untuk dosen juga untuk persyaratan ujian akhir strata dua hingga memudahkan proses dan caranya dalam menyelesaikan kuliah. Semua prsetasi tersebut dipengaruhi oleh kecerdasan intelektual dan emosional yang dimiliki subjek melalui proses serta upaya dalam mengembangkan potensi diri dari aspek kecerdasan intelektual juga emosional tersebut (Daud, 2012)

\section{SIMPULAN}

Berdasarkan hasil penelitian yang diperoleh, maka peneliti menarik kesimpulan bahwa proses dan cara yang ditempuh oleh mahasiswa tersebut adalah dengan cara membiasakan diri, dalam belajar meskipun memiliki keterbatasan ekonomi dalam keluarga. Keterbatasan ekonomi tersebut tetap memberinya semangat dalam meraih citacita dan tujuan berdasarkan bentuk dan upaya yang dia lakukan dengan cara mengenali diri sendiri dan memotivasi diri dalam belajar. Proses yang dilakukan dalam membiasakan diri adalah dimulai dari waktu yang singkat untuk menyesuaikan kondisi belajar dengan kemampuan dengan bentuk upaya bangun pagi dan membuat jadwal pelajaran secara konsisten hingga menghasilkan pengetahuan yang luas dari sisi intelektual dan pengelolahan emosi diri dalam belajar. Selain itu proses keterbatasan ekonomi yaitu dilihat dari kondisi keluarga subjek yang hidup dalam keadaan yang paspasan dengan upaya yang dilakukan adalah mencari beasiswa dan mengajar menjadi dosen muda hingga menghasilkan pengetahuan intelektual yang kuat dalam menjadi dosen sekaligus kemauan untuk memenuhi keterbatasan ekonomi yang merupakan dorongan dari kecerdasan emosional. Kemudian dengan proses mengenali diri akan kemampuan dalam belajar melalui bentuk upaya melakukan tes akademik dan kepribadian untuk mengetahui kemampuan dalam belajar serta mencoba berbagai macam cara belajar hingga menghasilkan pengetahuan kuat berdasarkan cara belajar yang sesuai dengan kenyamanan diri. Terakhir motivasi diri dengan proses perkuliahan yang akan memudahkan cita-citanya menjadi guru besar dan peneliti bidang farmasi melalui bentuk upaya yakni mencari dukungan dari orang tua dan bergaul dengan teman yang memberi pengaruh positif serta belajar dari kisah-kisah sukses para tokoh di masa lampau. Hasil yang ditimbulkan yakni berupa beasiswa yang dapat membantunya untuk tetap kuliah dalam keadaan keterbatasan ekonomi serta menjadi asisten dosen dan mendapat banyak proyek penelitian yang dapat membantunya dalam menyelesaikan kuliah.

\section{UCAPAN TERIMAKASIH}

Penulis mengucapkan terima kasih yang sebanyak-banyaknya kepada pihakpihak yang telah membantu dalam bentuk support seperti, pihak pasca sarjana UIN Sunan Kalijaga dalam menunjang proses perkulaihan peneliti penelitian untuk menunjang proses penelitian ini dan Rafika sahabat sekelas yang membantu penelitian ini agar berjalan dengan lancar. Bantuan tersebut baik materil maupun moril yang datang dari semua kalangan dan pihak untuk kesempurnaan penelitian ini, maka peneliti mengucap syukur dan rasa terima kasih yang sedalam-dalamnya serta doa kepada pihak-pihak tersebut yang berkontibusi dan memberikan sumbangsi semoga selalu dalam ridho dan lindungan Allah, Swt. amin 


\section{DAFTAR PUSTAKA}

Abdurrahman, M. (2003). Pendidikan bagi anak berkesulitan belajar. Jakarta: Rineka Cipta.

Ahmadi, A., \& Supriyono, W. (2007). Psikologi Belajar, cetakan ke 2. Jakarta: PT Rieneka Cipta.

Bowles, T. (2008). Self-rated Estimates of Multiple Intelligences Based on Approaches to Learning. Australian Journal of Educational \& Developmental Psychology, 8, 15-26.

Choiriah, A. (2013). Pengaruh Kecerdasan Emosional, Kecerdasan Intelektual,

Kecerdasan Spiritual Dan Etika Profesi Terhadap Kinerja Auditor Dalam Kantor Akuntan Publik. Jurnal Akuntansi, 1(1).

Daud, F. (2012). Pengaruh kecerdasan emosional (EQ) dan motivasi belajar terhadap hasil belajar Biologi siswa SMA 3 Negeri Kota Palopo. Jurnal Pendidikan dan Pembelajaran (JPP), 19(2), 243-255.

Dewi, I. S. (2011). Pengaruh Kecerdasan Emosional, Persepsi Kode Etik, Tekanan Waktu, dan Motivasi terhadap Kinerja Auditor pada Kantor Akuntan Publik di Kota Semarang [PhD Thesis]. Universitas Negeri Semarang.

Dewi, S. (2018). HUBUNGAN ANTARA DUKUNGAN SOSIAL TEMAN SEBAYA DAN KEPERCAYAAN DIRI AKADEMIK DENGAN REGULASI DIRI DALAM BELAJAR PADA MAHASISWA DI UNIVERSITAS X [PhD Thesis]. Fakultas Psikologi UNISSULA. Gardner, H. (2003). Multiple Intelligences; Kecerdasan Majemuk Teori dalam Praktek. Batam: Interaksara.

Gusniwati, M. (2015). Pengaruh kecerdasan emosional dan minat belajar terhadap penguasaan konsep matematika siswa SMAN di kecamatan Kebon Jeruk. Formatif: Jurnal Ilmiah Pendidikan MIPA, 5(1).

Havighurst, R. J. (1948). Developmental tasks and education. University of Chicago Press. 
Hendriana, E. C., \& Jacobus, A. (2017). Implementasi Pendidikan Karakter di Sekolah melalui Keteladanan dan Pembiasaan. JPDI (Jurnal Pendidikan Dasar Indonesia), 1(2), $25-29$.

Herawaty, D. (2016). Pengaruh kecerdasan emosional, partisipasi guru dalam forum ilmiah, keyakinan diri (self efficacy), dan motivasi kerja terhadap kinerja guru matematika. Jurnal Review Pembelajaran Matematika, 1(1), 71.

Holloway, C. D., Immy. (2007). Metode-Metode Riset Kualitatif dalam Public Relations dan Marketing Communications. Bentang Pustaka.

Ihsani, N., Kurniah, N., \& Suprapti, A. (2018). Hubungan metode pembiasaan dalam pembelajaran dengan disiplin anak usia dini. Jurnal Ilmiah Potensia, 3(2), 105-110. Indonesia, K. B. B. (t.t.). Edisi ke 3. 2000. Depdiknas. Jakarta: Balai Pustaka. Leinonen, J. A., Solantaus, T. S., \& Punamäki, R.-L. (2002). The specific mediating paths between economic hardship and the quality of parenting. International journal of behavioral development, 26(5), 423-435.

Majdi, U. Y. E. (t.t.). Quranic Quotient. QultumMedia.

Mangal, S. K. (2002). Advanced educational psychology. PHI Learning Pvt. Ltd. Melandy, R., \& Nurma, A. (2006). Pengetahuan Kecerdasan Emosional Terhadap Pemahaman Akuntansi Kepercayaan Diri sebagai Variabel Pemoderasi. Padang: Jurnal Simposium Nasional Akuntansi IX.

Muthoharoh, A. I. (2015). Pendidikan Nasionalisme Melalui Pembiasaan Di SD Negeri Kuningan 02 Semarang Utara. Unnes Civic Education Journal, 1(2).

MZ, A. P. (2018). PELAKSANAAN PENGELOLAAN KELAS DALAM MENINGKATKAN MOTIVASI BELAJAR SISWA PADA MATA PELAJARAN RUMPUN IPS DI SMA NEGERI 11 PANGKEP [PhD Thesis]. UNIVERSITAS NEGERI MAKASSAR. Nurwati, N. (2008). Pengaruh kondisi sosial dan ekonomi keluarga terhadap motivasi pekerja anak dalam membantu keluarga di kabupaten cirebon, Jawa Barat. Jurnal Kependudukan Padjadjaran, 10(2), 112. 
Periantalo, J., \& Azwar, S. (2017). Pengembangan skala kepribadian siswa SMA dari tipologi kepribadian Jung dan Myers-Briggs. Jurnal Sains Sosio Humaniora, 1(2), 191207.

Pranita, S. (2012). Prestasi Belajar Ekonomi Ditinjau Dari Disiplin Belajar Dan Komunikasi Guru Siswa Kelas VII SMP N 2 Sawit Boyolali 2011/2012 [PhD Thesis]. Universitas Muhammadiyah Surakrta.

Prawira, P. A., \& Atmaja, P. (2012). Psikologi pendidikan dalam perspektif baru. ArRuzz Media.

Purwanto, M. (t.t.). Ngalim. 2003. Psikologi Pendidikan. Bandung: PT Remaja Rosdakarya.

Rachmi, F. (2011). Pengaruh Kecerdasan Emosional, Kecerdasan Spiritual, Dan Perilaku Belajar Terhadap Tingkat Pemahaman Akuntansi (Studi Empiris pada Mahasiswa Akuntansi Universitas Diponegoro Semarang dan Universitas Gajah Mada Yogyakarta) [PhD Thesis]. Universitas Diponegoro.

Rahmawati, A. (2018). Pengaruh Kecerdasan Emosional, Perilaku Belajar Dan Budaya Terhadap Tingkat Pemahaman Akuntansi Dengan Kepercayaan Diri Sebagai Variabel Pemoderasi Pada Mahasiswa Universitas Muhammadiyah Surakarta Dan Universitas Islam Batik Surakarta Di Surakarta [PhD Thesis]. Universitas Muhammadiyah Surakarta. Saidin, O. K. (2004). Aspek hukum hak kekayaan intelektual (Intellectual property rights).

Sari, I. P. (2017). SISTEM INFORMASI MANAJEMEN DALAM PENGEMBANGAN SUMBER DAYA MANUSIA DAN KOMUNIKASI KARYAWAN LP3I CABANG PEKANBARU. Jurnal Ilmiah Media Sisfo, 10(1), 485-496. http://ejournal.stikomdb.ac.id/index.php/mediasisfo/article/view/201

Semiawan, C. R. (2010). Metode penelitian kualitatif. Grasindo.

Setiawan, A. A., Johan. (2018). Metodologi penelitian kualitatif. CV Jejak (Jejak Publisher). 
Suciani, D., \& Safitri, S. (2014). Hubungan dukungan sosial dengan motivasi belajar pada mahasiswa Universitas Esa Unggul. Jurnal Psikologi Esa Unggul, 12(02), 126710.

Surya, H. (2013). Strategi jitu mencapai kesuksesan belajar. Elex Media Komputindo.

Syah, M. (2009). Psikologi Belajar (edisi revisi). Jakarta: Rajawali.

Syaputra, R. Z. A., Asrori, M., \& Yuline, Y. (t.t.). PENGARUH LAYANAN

ORIENTASI TERHADAP KEMANDIRIAN BELAJAR KELAS X SMAIT AL-

FITYAN KABUPATEN KUBU RAYA. Jurnal Pendidikan dan Pembelajaran

Khatulistiwa, 7(9).

Ulfah, K. R., Santoso, A., \& Utaya, S. (2016). Hubungan motivasi dengan hasil belajar IPS. Jurnal Pendidikan: Teori, Penelitian, dan Pengembangan, 1(8), 1607-1611.

Ulwiyah, N. (2015). Landasan Psikologi Dan Aktualisasinya Dalam Pendidikan Islam. Religi: Jurnal Studi Islam, 6(1), 76-99.

Utomo, P. (2011). Analisis Kontribusi Pemberian Beasiswa terhadap Peningkatan

Prestasi Akademik Mahasiswa Fakultas Teknik Universitas Negeri Yogyakarta. Jurnal Pendidikan Teknologi dan Kejuruan, 20(1), 67-87.

Werther Jr, W. B., \& Davis, K. (1985). PERSONNEL MANAGEMENT AND HUMAN

RESOURCES. https://trid.trb.org/view/281388

Yani, F. (2011). Pengaruh Kecerdasan Intelektual, Kecerdasan Emosional, Kecerdasan Spiritual Terhadap Pemahaman Akuntansi. Jurnal Akuntansi Pendidikan. Universitas Riau. 